\title{
THE INFLUENCE OF THE HUMAN FACTOR ON COMPETITIVENESS OF ENTERPRISES IN THE METAL PROCESSING INDUSTRY IN CROATIA
}

\author{
Lena Duspara, Željko Požega, Boris Crnković
}

Original scientific paper

The human factor is one of the fundamental and most important elements in the process of achieving competitive position of enterprise. For this reason, it is necessary to develop a strategy that will contribute to the prosperity and constant development of human resources in the company. One of the most significant and geographically most widespread industries in the Republic of Croatia is the metal processing industry. This industry does not currently have successful financial indicators and is heavily indebted. The aim of this paper is to show the impact of employees on the success of the enterprise. Therefore, the influence of the human factor on the competitiveness of enterprises in this industry is shown in the paper.

Keywords: competitiveness; metal processing; net profit; strategy

Utjecaj ljudskog faktora na konkurentnost poduzeća u metaloprerađivačkoj industriji u RH

Izvorni znanstveni članak

Ljudski faktor je jedan od temeljnih i najvažnijih elemenata u procesu postizanja konkurentske pozicije poduzeća. Upravo stoga, potrebno je razvijati strategiju koja će pridonijeti prosperitetu i stalnom razvoju ljudskog kadra u poduzeću. Jedna od najznačajnijih i geografski najrasprostranjenijih industrijskih grana na području Republike Hrvatske je metaloprerađivačka industrija. Ova industrija trenutno nema uspješne financijske pokazatelje i prezadužena je. Upravo se ovim radom želi prikazati utjecaj zaposlenika na uspješnost poduzeća. Odnosno, prikazuje se utjecaj ljudskog faktora na konkurentnost poduzeća u ovoj industriji.

Ključne riječi: konkurentnost; metaloprerađivačka industrija; neto dobit; strategija

\section{Introduction}

Metal processing industry exerts one of the strongest influences on the manufacturing industry, but also on the economy in the Republic of Croatia. In a global postindustrial economy the role of company strategy is becoming increasingly important. This is particularly significant for a small transition country such as Croatia. Strategy is used for improving performance and management, and as a tool for achieving competitive advantage. The aim of this paper is to present the current state of the metal processing industry in the Republic of Croatia - based on research. The research is conducted on enterprises in the metal processing industry and presents the connection of revenue per employee and the financial indicators of the company. It shows the impact of human activity, respectively how the revenue per employee has an impact on earnings per employee.

"Power of the national economy is reflected in the strength of its industry. Countries with strong, developed and industrial production have good macroeconomic indicators and high standard of living." [1]

"Competitiveness is the foundation that determines the success or failure of the company. It determines the suitability of the company's activities that contribute to its performance, such as innovation, cohesive organizational culture or good implementation. Competitive strategy is the search for a favorable competitive position within the industry, the basic environment in which competition occurs. Competitive strategy is focused on establishing a profitable and sustainable position despite the forces that determine industry competition." [2]

The interest of every country is to compete and that the industry is export-oriented. The state should strengthen and develop the economic part of its diplomatic missions, at least in the country's largest trading partners. To be competitive in the demanding EU and other markets is the task, for companies, as well as for all state institutions.

\section{Analysis of the metal processing industry in Croatia}

"The metal-processing industry is one of the most important industries in the Republic of Croatia, which holds a key position in the structure of the economy, while at the same time it represents one of the leading export activities. Businesses are focused on: exports, introduction of new technologies, training skilled personnel, certification of the system of quality, environmentally friendly production, and connection with domestic and foreign manufacturers. The production program of the metal processing industry in Croatia is very diverse and could meet all the needs of potential customers and partners. Entrepreneurs in the sector continue to strengthen, and this is reflected in an increase of their production capacity, new products and higher exports. "[3]

The analysis of the metal processing industry is based on three sectors - according to NKD 2007 (NKD-National Classification of Activities), these sectors are: C24, C25 and $\mathrm{C} 28$ :

- $\quad$ C24 - Manufacture of basic metals

- C25 - Manufacture of fabricated metal products, except machinery and equipment

- $\quad$ C28 - Manufacture of machinery and equipment

"Activity C24 includes melting and / or refining ferrous and unwanted metals from ore or scrap, using electrometallurgical or other metallurgical techniques. Activity C25 includes the manufacture of "pure" metal products (such as parts, containers and structures). Activity C28 includes the manufacture of machinery and 
equipment that act independently on materials either mechanically or thermally, or perform operations on materials, including their mechanical components, that produce and apply force, and any specially manufactured primary parts. "[4] Table 1 shows the basic indicators of the metal processing industry in Croatia.

Table 1Analysis of the metal processing industry in the Republic of Croatia [4]

\begin{tabular}{|c|c|c|c|c|c|c|c|c|c|c|c|}
\hline & $\begin{array}{c}\text { Number of } \\
\text { enterprises }\end{array}$ & $\begin{array}{c}\text { Number of } \\
\text { employees }\end{array}$ & $\begin{array}{c}\text { Net } \\
\text { salary } \\
\text { (HRK) }\end{array}$ & $\begin{array}{c}\text { Total revenue } \\
\text { (HRK) }\end{array}$ & $\begin{array}{c}\text { The difference } \\
\text { profit or loss } \\
\text { after tax } \\
\text { (HRK) }\end{array}$ & $\begin{array}{c}\text { Gross value } \\
\text { added (HRK) }\end{array}$ & $\begin{array}{c}\text { ROA } \\
(\%)\end{array}$ & $\begin{array}{c}\text { ROE } \\
(\%)\end{array}$ & $\begin{array}{c}\text { The ratio } \\
\text { Current } \\
\text { ratio } \\
\text { of exports } \\
\text { and } \\
\text { imports }\end{array}$ \\
\hline C24 & 122 & 4787 & 55596 & 4701749768 & 363905209 & 1193334794 & 8,31 & 69,52 & 0,527 & 0,829 & 1,322 \\
\hline C25 & 1861 & 26950 & 56026 & 11896808737 & 593764836 & 4110882605 & 4,46 & 13,83 & 1,169 & 0,644 & 2,237 \\
\hline C28 & 589 & 10699 & 60909 & 5761966575 & 167058729 & 1743157518 & 2,76 & 11,73 & 1,083 & 0,715 & 2,641 \\
\hline
\end{tabular}

Table 1 shows that the largest number of registered enterprises and the largest number of employees is in sector C25. The largest deviation is at the ROE - 69, $52 \%$ (return of equity) for sector $\mathrm{C} 24$, while a healthy enterprise should have about $15 \%$. Also the gearing ratio of all sectors is too high and should amount to $0,5 \%$ and less. This industry has a high level of imports and exports. The reason for the high rate of imports is that the domestic market almost does not have manufacturers of raw materials for the metal processing industry. The reason is that the larger enterprises in the transition process are mostly destroyed. Therefore, enterprises are forced to import components.

\section{Structure of human resources in the metal processing industry}

The metal processing industry is of great importance to the processing industry in the Republic of Croatia. Metal industry makes more than $1 / 5$ of all registered enterprises in the industrial production, as can be seen in table 2 below.

Table 2 The number of companies in the metal processing industry and the entire manufacturing industry of the Republic of Croatia in the period from $2008 \div 2012$ (made by author according to data taken from the Croatian Chamber of Economy- County Chamber Slavonski Brod [5])

\begin{tabular}{|c|c|c|c|c|c|}
\hline & 2012 & 2011 & 2010 & 2009 & 2008 \\
\hline $\mathrm{C}$ & 10621 & 10771 & 10640 & 9851 & 9736 \\
\hline $\mathrm{C} 24$ & 105 & 109 & 106 & 105 & 107 \\
\hline $\mathrm{C} 25$ & 1726 & 1752 & 1746 & 1612 & 1540 \\
\hline $\mathrm{C} 28$ & 558 & 562 & 579 & 538 & 570 \\
\hline$\Sigma(\mathrm{C} 24, \mathrm{C} 25, \mathrm{C} 28)$ & 2389 & 2423 & 2431 & 2255 & 2217 \\
\hline$\% \Sigma \mathrm{u} C$ & $22,49 \%$ & $22,49 \%$ & $22,84 \%$ & $22,89 \%$ & $22,77 \%$ \\
\hline
\end{tabular}

Tab. 2 shows that in the given time period (2008.2012.), the total number of enterprises in the metal processing industry $\Sigma(\mathrm{C} 24, \mathrm{C} 25, \mathrm{C} 28)$ has increased, but the share of the metal processing industry in total manufacturing (\% sums in C) has remained the same. As the sector of the metal processing industry is growing, proportionally the total manufacturing industry is growing. It can be concluded that the number of enterprises in the metal processing industry has a significant impact on the manufacturing industry, because the share of enterprises in the metal processing industry within the manufacturing industry is over $22 \%$. So, the metal industry makes one fifth of the enterprises in the manufacturing industry, which is a very significant share. The number of enterprises in the metal processing industry has a significant impact on the processing industry in the Republic of Croatia. According to a large number of registered enterprises, this industry has a significant share of net salaries, as is shown below in Tab. 3.

Table 3 Wages and salaries in the metal processing industry and the overall manufacturing industry of the Republic of Croatia in the period from $2008 \div 2012$ (made by author according to data from Croatian Chamber of Economy [5])

\begin{tabular}{|l|c|c|c|c|c|}
\hline & 2012 & 2011 & 2010 & 2009 & 2008 \\
\hline $\mathrm{C}$ & 12284875500 & 12405403437 & 12453570065 & 12636027764 & 13165461946 \\
\hline $\mathrm{C} 24$ & 258796458 & 280565993 & 295053753 & 302570024 & 345379281 \\
\hline $\mathrm{C} 25$ & 1440428849 & 1315210472 & 1258761454 & 1218444436 & 1158556841 \\
\hline $\mathrm{C} 28$ & 637527893 & 608203058 & 582850256 & 593036780 & 639923897 \\
\hline$\Sigma(\mathrm{C} 24, \mathrm{C} 25, \mathrm{C} 28)$ & 2336753200 & 2203979523 & 2136665463 & 2114051240 & 2143860019 \\
\hline$\% \Sigma \mathrm{u} \mathrm{C}$ & $19,02 \%$ & $17,76 \%$ & $17,15 \%$ & $16,73 \%$ & $16,28 \%$ \\
\hline
\end{tabular}

Tab. 3 shows that in the given time period, the amount of net salaries in the manufacturing industry has reduced in comparison with the year 2008. In the metal industry the trend is reversed, and the amount of net salaries slowly grows towards 2012. That is, the percentage share of salaries and wages in the metal processing industry is constantly increasing each year in the total processing industry, with an average of $0.5 \%$ annually. From this it can be concluded that the net salaries from the metal processing industry have a significant impact on the processing industry of Croatia.

Although the share of enterprises, net salary and the number of employees in the metal processing industry is very important in relation to the entire industry, the industry does not achieve a proportionately high level of profit. The reason for this to happen is inefficiency because of low technological equipment and unfavorable educational structure (very small number of highly 
educated who have skills, competence and ability for creating new values, which is based on the knowledge and application of new technologies). The profit of the metal processing industry is shown in Tab. 4.

Table 4 Profit for the period in the engineering industry and the entire manufacturing industry of the Republic of Croatia in the period from $2008 \div 2012$ (made by author according to data taken from the Croatian Chamber of Economy [5])

\begin{tabular}{|c|c|c|c|c|c|}
\hline & 2012 & 2011 & 2010 & 2009 & 2008 \\
\hline $\mathrm{C}$ & 14545470150 & 12739659068 & 7554203853 & 5924398179 & 6761361822 \\
\hline $\mathrm{C} 24$ & 622894257 & 37684638 & 20723828 & 15944205 & 29892550 \\
\hline $\mathrm{C} 25$ & 1014663746 & 706264174 & 566168600 & 580712862 & 625999076 \\
\hline $\mathrm{C} 28$ & 351116915 & 361118254 & 228869307 & 218517756 & 271925496 \\
\hline$\Sigma(\mathrm{C} 24, \mathrm{C} 25, \mathrm{C} 28)$ & 1988674918 & 1105067066 & 815761735 & 815174823 & 927817122 \\
\hline$\% \Sigma \mathrm{u} \mathrm{C}$ & $13,67 \%$ & $8,67 \%$ & $10,79 \%$ & $13,75 \%$ & $13,72 \%$ \\
\hline
\end{tabular}

Tab. 4 shows that in the observed period, the earnings of the manufacturing industry have grown in comparison with the earnings in the year 2008, and at the growing rate of $17 \%$ in the time period between $2010 \div 2011$. The metal processing industry also recorded an upward trend towards 2012 but at a much lower rate than the industry average. The profit of the metal processing industry in the total manufacturing industry year in year out does not record growth. From the year 2008 to 2009 there was stagnation, from 2009 there was a steady decline in the share, but in 2012 the share is growing. Therefore, it can be concluded that the profits of the metal processing industry do not have a significant impact on the manufacturing industry of the Republic of Croatia in the same proportion as the number of firms and net wages and salaries. Due to this situation, enterprises in the metal processing industry should take strategic actions to maximize their profits, and thus get a larger share of the profit in the total manufacturing industry.

\section{Research-analysis sample}

The study was conducted on 508 enterprises in the metal processing industry, of which $502(98,8 \%)$ are private, and $6(1,2 \%)$ are state-owned. Indicators and data about the enterprises are downloaded from the portal Business Croatia [6]. Central year of establishing of the enterprises is 1997 (interquartile range from 1992 to 2007, which means that $50 \%$ of surveyed enterprises were established in this interval), the oldest company was founded in 1921 and the youngest in 2014. The number of board members ranges from 1 to 6 members, the mean 1 (interquartile range $1 \div 2$ ), while the average number of employees is 7 (interquartile range $1 \div 33$ ), including enterprises that do not have employees, to companies with 1698 employees. Average net wage is 3780 HRK (interquartile range 2070 to $5065 \mathrm{HRK}$ ). Most of them $492(96,9 \%)$ is privately owned. Mostly private property has got $7(1,4 \%)$ enterprises (more than $50 \%$ of private capital). Two companies $(0,4 \%)$ are in state ownership which has not started conversion $(0,4 \%)$, and two in the state ownership are in the process of conversion. The cooperative ownership has only $2(0,4 \%)$ companies.

By activity, $35(6,9 \%)$ enterprises are in the production of metals business, $370(72,8 \%)$ in the production of fabricated metal products (except machinery and equipment) business, and 100 (19,7\%) are in the manufacturing of machinery and equipment business. Three companies are in the activity of sale and repair of motor vehicles and motorcycles, as well as activities in the field of trade.
According to company size there are: 400 small $(78,3$ $\%$ ), 93 medium (18,3\%), and 15 large (3\%) companies. The source of capital in 447 (88\%) of the companies is $100 \%$ domestic, only one company has $100 \%$ private capital, $100 \%$ foreign capital is in $47(9,3 \%)$ companies, while other companies have a certain percentage of foreign capital. For three $(0,6 \%)$ companies there is no information for the source of capital.

\section{The impact of revenue per employee on the net profit per employee in the metal industry}

There is a hypothesis for this research: Companies with higher revenue per employee in the metal industry have a larger net profit per employee. Spearman's correlation coefficient, which represents a non-parametric equivalent to Pearson's correlation coefficient (the product of rank correlation), will be used for the evaluation of integration, in order to measure the association between variables (total revenue and revenue per employee with the observed parameters: company size, year of establishment, number of members in the management board, total revenues and expenses, EBITDA, EBIT, EBT, income taxes, net income, added value, productivity, money, exports and imports, assets / liabilities, fixed and current assets and equity, current ratio, Altman $\mathrm{Z}$ score, turnover days and obligations in the days, operating margin, cash cycle days, ROE, ROA, revenue per employee and net profit per employee).

It is based on how to measure the consistency of the association between variables lined up, and the form of connection (e.g. a linear shape which is a prerequisite for using Pearson coefficient) is not important.

A case in which Spearman coefficient is used is for example, when there is a linear relationship between the variables, but it is not possible to apply the appropriate transformation that would translate into a linear connection. Spearman's correlation coefficient as a result gives the approximate value of the correlation coefficient, which is treated as its good enough approximation.

Calculation of the coefficient is made in a way to use the value assigned to ranges. Spearman coefficient indicated by the Rho $(\rho)$. The basis of Spearman rank correlation coefficient couples modalities ranking variables or numerical variables transformed into ranking variables. Modalities of each rank-variable are from the set of the first $n$ natural numbers. If in each pair ranks are equal, their differences are equal to zero, and the coefficient takes the value 1 , in this case it is the case of completely positive correlation rank. When the order of the modalities of one rank-variable is reversed, the order 
of the other variables in pairs, the coefficient will take the value of -1 , and the score integration complete and negative direction. If the significance level is 0,05 , the decision is made by comparing the test size (rank correlation coefficient of the sample) which has critical value sampling-distribution of rank correlation coefficient for the probability or significance level and sample size. An alternative hypothesis contains the opposite assertion that there are tendencies that have great value of one variable paired with high values of other variables (positive correlation) or that large values of one variable associated with small values of other variables (negative correlation). For the value of the correlation, if the coefficient is greater than 0,5 and less than 0,5 it is said to be good, or if the value is closer to 1 or -1 connection is excellent.

For the purposes of the test two assumptions will be set:

H1.1: There is no correlation between total revenue and revenue per employee and observed parameters,

H1.2: there is a correlation between the total revenue, or revenue per employee and the observed parameters.

In this test the level of significance is set at $\alpha=0,05$. So, if the level of significance of the test is less than $5 \%$ (significance level of $5 \%$ is equal to $95 \%$ ) assumption $\mathrm{H} 1.1$ will be rejected and the alternative hypothesis H1.2 will be accepted. There will be a significant relationship of total expenditure or the average net salary and the observed parameters. If significance is greater than $5 \%$, H1.2 will be rejected and H1.1 will be accepted. Otherwise, statistically significant correlation between the total expenditure and the average net salary and the observed parameters will not be proven.

After the correlation analysis, univariate and multivariate regression analyses are carried out with which it is able to see how many of the predictors have impact on total revenue, or revenue per employee, and the impact model (all significant predictors of univariate analysis) on total revenue and revenue per employee ( the dependent variable).

Correlation adjacency matrix of total revenues with the observed parameters shows that all parameters are statistically significantly correlated with the observed parameters. The highest level of correlation shows the next predictors: total expenditures $(\rho=0,990)$, added value $(\rho=0,958)$, current assets $(\rho=0,899)$, total assets / liabilities $(\rho=0,877)$ and accounts receivable $(\rho=0,858)$. The weakest positive correlation is with the rate of return on equity $(\mathrm{ROE})(\rho=0,162)$. A negative correlation and the total income are inversely proportional to company size, year of establishment, days binding assets and liabilities.

Table 5 Spearman's correlation coefficient of total revenue and revenue per employee and observed parameters (made by author)

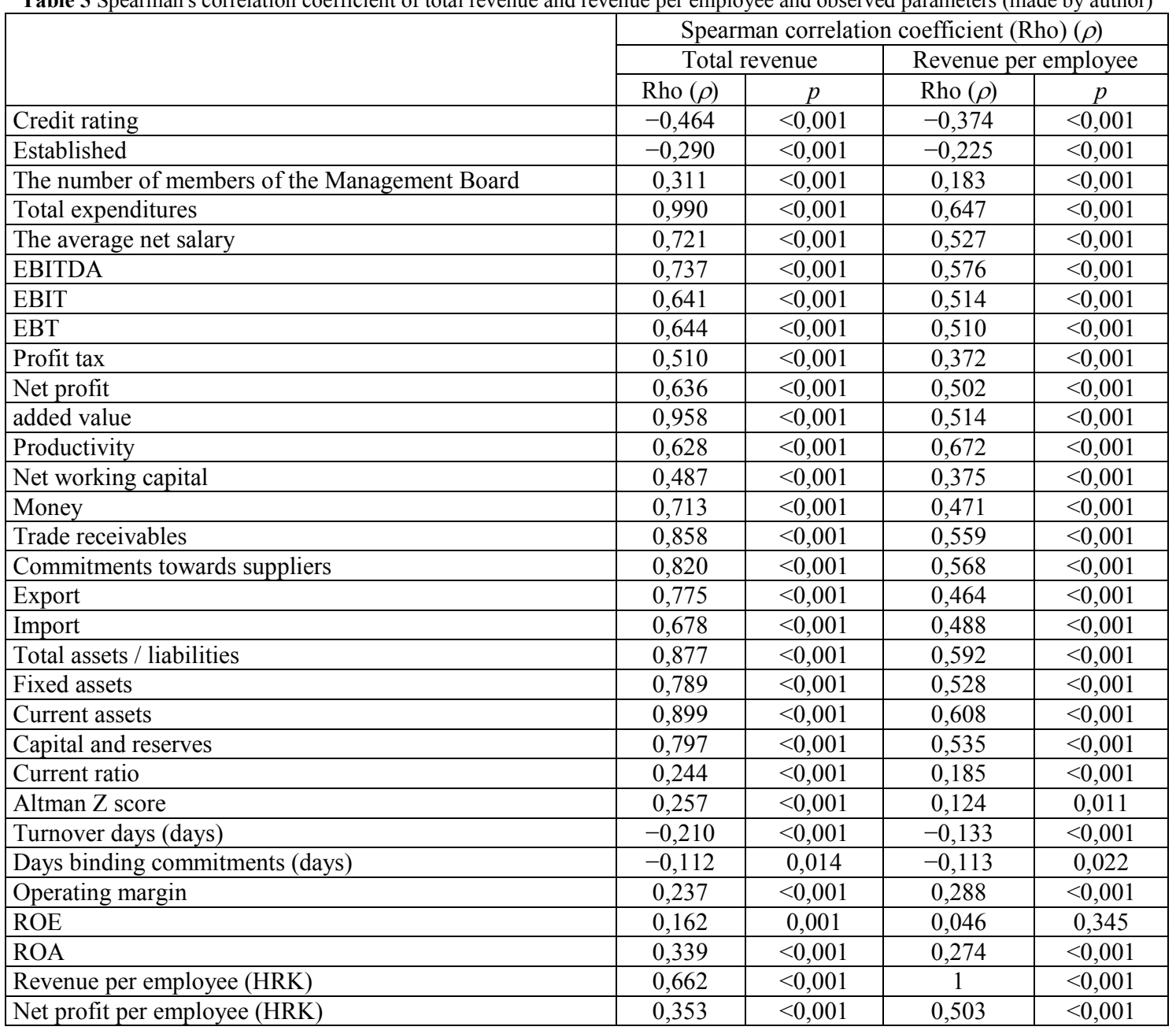


Correlation adjacency matrix revenue per employee with the observed parameters shows that all parameters are statistically significantly correlated with the observed parameters, except the rate of return on equity (ROE) ( $\rho=$ $0,046, p=0,345)$. The highest level of correlation shows variables: total expenditure $(\rho=0,647)$, productivity $(\rho=$ $0,0672)$, and the value of current assets $(\rho=0,608)$. The lowest positive correlation has connections with the Altman $Z$ Score $(\rho=0,124)$. Negative correlation of revenues per employee is with the company size, year of establishment, days binding claims and binding obligations (Tab. 5).

Spearman's correlation coefficient (Tab. 5) gives the rating association of total revenue, or revenue per employee with the observed parameters. It exhibits good correlation (greater than 0,500 ), the average net salary or total expenditures with most parameters. As the correlation coefficient (Rho) $\rho>0,5$ and the significance of less than 0,05, assumption H1.2 is accepted - by increase of total revenue and net income increases too $(\rho$ $=0,644, p<0,001$ ).

From the above it is clear that the hypothesis is confirmed.

To avoid erroneous signs of regression coefficients, the statistical insignificance of some independent variables that are actually significant in relation to the dependent variable (total revenues and revenues per employee), and vice versa, the independent variables strongly correlated with each other are excluded from further analysis.

In the univariate analysis variables such as the following remain: company size, number of members of the administration, tax, productivity, money, trade, import, current ratio, Altman $Z$ Score, revenue per employee and net profit per employee. On the total income an individual significant impact has: credit rating, the number of board members, tax, productivity, money, trade, and import and revenue per employee. The following parameters affect the revenue per employee: productivity, money, trade, import and net profit per employee (Tab. 6 and Tab. 7).

Table 6 The individual effect parameters to change the total revenue univariate regression analysis (made by author)

\begin{tabular}{|l|c|c|c|}
\hline \multicolumn{1}{|c|}{ Parameter } & $\begin{array}{c}\text { Standardized } \\
\text { coefficient } \beta\end{array}$ & $t$ & $p$ \\
\hline Credit rating & $-0,164$ & $-3,555$ & $<0,001$ \\
\hline $\begin{array}{l}\text { The number of members of } \\
\text { the Management Board }\end{array}$ & 0,329 & 7,412 & $<0,001$ \\
\hline Profit tax & 0,264 & 6,156 & $<0,001$ \\
\hline Productivity & 0,146 & 3,044 & $<0,002$ \\
\hline Money & 0,594 & 16,605 & $<0,001$ \\
\hline Trade receivables & 0,746 & 25,184 & $<0,001$ \\
\hline Import & 0,799 & 29,94 & $<0,001$ \\
\hline Current ratio & $-0,032$ & $-0,713$ & 0,476 \\
\hline Altman Z score & 0,016 & 0,348 & 0,728 \\
\hline $\begin{array}{l}\text { Revenue per employee } \\
\text { (HRK) }\end{array}$ & 0,208 & 4,334 & $<0,001$ \\
\hline $\begin{array}{l}\text { Net profit per employee } \\
\text { (HRK) }\end{array}$ & 0,024 & 0,488 & 0,626 \\
\hline
\end{tabular}

As a model that has the greatest effect on total expenditures predictors that are significant are observed (company size, number of board members, tax, productivity, money, trade, and import and revenues per employee).

Table 7 Individual parameters' impact on the change in revenue per employee - univariate regression analysis (made by author)

\begin{tabular}{|l|c|c|c|}
\hline \multicolumn{1}{|c|}{ Parameter } & $\begin{array}{c}\text { Standardized } \\
\text { coefficient } \beta\end{array}$ & $t$ & $p$ \\
\hline Credit rating & $-0,085$ & $-1,699$ & 0,090 \\
\hline $\begin{array}{l}\text { The number of members } \\
\text { of the Management Board }\end{array}$ & 0,079 & 1,527 & 0,128 \\
\hline Profit tax & 0,062 & 1,273 & 0,204 \\
\hline Productivity & 0,655 & 17,564 & $<0,001$ \\
\hline Money & 0,117 & 2,387 & 0,017 \\
\hline Trade receivables & 0,204 & 4,249 & $<0,001$ \\
\hline Import & 0,194 & 4,021 & $<0,001$ \\
\hline Current ratio & $-0,018$ & $-0,368$ & 0,713 \\
\hline Altman Z score & 0,032 & 0,653 & 0,514 \\
\hline $\begin{array}{l}\text { Net profit per employee } \\
\text { (HRK) }\end{array}$ & $-0,446$ & $-10,14$ & $<0,001$ \\
\hline
\end{tabular}

Finally, a model with four independent predictors is obtained, which is completely statistically significant, $p<$ 0,001 and completely explains $79,1 \%$ of the variance in revenue and 78,8 \% with correction. Five independent predictors give the unique statistically significant contribution model (number of members of the administration, tax, money, trade and imports). The strongest predictor of imports $(\beta=0,473)$ (Tab. 8).

Table 8 Final model of the impact of the change in total revenue multivariate regression analysis (made by author)

\begin{tabular}{|l|c|c|c|}
\hline \multicolumn{1}{|c|}{ Parameter } & $\begin{array}{c}\text { Standardized } \\
\text { coefficient } \beta\end{array}$ & $t$ & $p$ \\
\hline $\begin{array}{l}\text { The number of members of the } \\
\text { Management Board }\end{array}$ & 0,096 & 3,707 & $<0,001$ \\
\hline Profit tax & 0,073 & 2,820 & 0,005 \\
\hline Money & 0,174 & 5,883 & $<0,001$ \\
\hline Trade receivables & 0,353 & 11,395 & $<0,001$ \\
\hline Import & 0,473 & 14,751 & $<0,001$ \\
\hline Constant & & $-1,793$ & 0,074 \\
\hline
\end{tabular}

$R=0,889 ; R^{2}=0,791 ;$ Corrected $R^{2}=0,788 ; p<0,001$

Table 9 Final model of the impact on revenue per employee multivariate regression analysis (made by author)

\begin{tabular}{|l|c|c|c|}
\hline \multicolumn{1}{|c|}{ Parameter } & $\begin{array}{c}\text { Standardized } \\
\text { coefficient } \beta\end{array}$ & $t$ & $p$ \\
\hline Productivity & 0,600 & 13,85 & $<0,001$ \\
\hline Money & $-0,125$ & $-2,95$ & 0,003 \\
\hline Import & 0,217 & 5,36 & $<0,001$ \\
\hline $\begin{array}{l}\text { Net profit per employee } \\
\text { (HRK) }\end{array}$ & $-0,141$ & $-3,36$ & 0,001 \\
\hline Constant & & 0,347 & 0,518 \\
\hline
\end{tabular}

$R=0,695 ; R^{2}=0,484 ;$ Corrected $R^{2}=0,478 ; p<0,001$

In the model that has the greatest effect on the revenue per employee, predictors that are significant were observed (productivity, money, trade, import and net profit per employee). Ultimately, a model has been created with five independent predictors which are completely statistically significant, $p<0,001$ and explain $48,4 \%$ of the variance of revenue per employee, and with correction $-47,8 \%$. Four independent predictors give a single statistically significant contribution model (productivity, money, import and net profit per employee). The strongest predictor affecting predictor for 
the revenue per employee is productivity $(\beta=0,600)$ (Tab. 9).

Univariate analysis tested the effect of some independent predictors that would affect the change of total income and the income per employee: company size, number of board members, tax, productivity, money, trade, import, current ratio, Altman $Z$ Score, revenue per employee and net profit per employee.

Credit rating, the number of board members, tax, productivity, money, trade, and import and revenue per employee are all factors which have an individual significant impact on the total income. From predictor variables that independently significantly affect the dependent variable - change of the total revenue - a model has been created in which only the predictor variables current ratio, Altman $Z$ Score and net profit per employee (HRK) have no significant impact. The strongest predictor that affects the change in total revenue is import $(\beta=0,473)$. Standardized coefficient $\beta$ shows the number of standard deviations (deviation) with which the values of the dependent variable (change in total revenues) would be changed if the predictor (import) changed by one unit of standard deviation.

Parameters which affect the revenue per employee are: productivity, money, trade, import and net profit per employee. Significant predictor variables that independently significantly affect the dependent variable revenue per employee have established a model, in which the predictor variables: company size, number of board members, income taxes, current ratio and the Altman $\mathrm{Z}$ score have no significant impact. Productivity, money, trade, import and net profit per employee affect the revenue per employee. The strongest predictor affecting the revenue per employee is productivity $(\beta=0,600)$. The standardized coefficient $\beta$ shows the number of standard deviations (deviation) for which the values of the dependent variable (revenue per employee) would change if the predictor (productivity) was changed by one unit of standard deviation.

According to the results of research and hypothesis research, it can be concluded that for most companies competitive advantage is unique and changes over a long period. Successful companies are constantly looking for new competitive advantages and spend a lot of time doing market research. Such companies monitor their competitors' activities. Successful businesses are built on solid foundations which consist of quality, professional people, good service, tradition and authenticity.

It is necessary to create a working culture that will constantly maintain a competitive advantage, and constantly monitor the competition. Good companies are aware of the competition, and it is a good way of reaching competitive advantage.

\section{Conclusion}

"In addition to the human frame it is necessary to implement new and specialized technologies, as a water jet, CNC machine, and robotics, and so on." [7] The human factor together with new technologies can produce competitive advantage for enterprises in the metal processing industry.
The research has been carried out on a sample of 508 companies, so the hypothesis: companies with higher revenues per employee in the metal processing industry have a greater net profit per employee- is accepted. All set parameters (on selected sample) show a statistically significant association with total revenues of the company and the net profit per employee, except the indicator ROE. The predictor with the strongest impact (on the selected sample) on the change of the total revenue is import, and productivity has the greatest impact on the revenue per employee. As a final consideration of the study and according to the analysis of the proposed hypotheses, it can be concluded that the metal processing industry has a very great importance, not only for the domestic industry, but for the economy in general. However, this industry does not achieve good results and it is necessary to apply strategic models and methods to achieve the competitive position of regional leadership based on successful human factor.

\section{References}

[1] Duspara, L.; Knežević, S.; Duspara, M. Structure of manufacturing enterprises and their impact on economy in Brodsko Posavska County. $/ / 5^{\text {th }}$ International scientific symposium-Economy of Eastern Croatia-vision and growth, Ekonomski fakultet u Osijeku, (2016), pp. 156

[2] Porter, M. E. Konkurentska prednost: postizanje i održavanje vrhunskog poslovanja. // Masmedia, Zagreb, 2008, pp. 20

[3] Agencija za investicije i konkurentnost, URL: http://www.aik-invest.hr/sektori/metaloprerađivačkaindustrija, (05.08.2015)

[4] Industrrijska strategija Hrvatske 2014.-2020., Ministarstvo gospodarstva, http://www.mingo.hr/page/kategorija/ industrijska-strategija-republike-hrvatske-2014-2020 (28.03.2014)

[5] Hrvatska gospodarska komora - Slavonski Brod, URL: http://www.hgk.hr/category/zk/slavonski-brod (15.03.2015)

[6] PoslovnaHrvatska, http://www.poslovna.hr/Login.aspx? ReturnUrl $=\% 2 \mathrm{f}(13.01 .2015)$

[7] Monková, K.; Monka, P.; Čep, R.; Müllerova, J.; Bražina, D.; Duspara, M.; Factor analysis of abrasive water jet factors affecting the surface roughness of titanium. // Technical Gazzete 18, 1(2011), pp. 73-77.

\section{Authors' addresses}

Lena Duspara, PhD, Lecturer

College of Slavonski Brod,

Ul. Dr. Mile Budaka 1, 35000 Slavonski Brod, Croatia

E-mail: lena.duspara@vusb.hr

Željko Požega, PhD, Associate Professor

Faculty of Economics in Osijek,

Trg Ljudevita Gaja 7, 31000 Osijek, Croatia

E-mail: zpozega@efos.hr

Boris Crnković, PhD, Associate Professor

Faculty of Economics in Osijek,

Trg Ljudevita Gaja 7, 31000 Osijek, Croatia

E-mail: bcrnko@efos.hr 